\title{
Mortality and lead exposure: a retrospective cohort study of Swedish smelter workers
}

\author{
L GERHARDSSON, ${ }^{1-3}$ N-G LUNDSTRÖM, ${ }^{1}$ G NORDBERG, ${ }^{1}$ S WALL
}

From the Departments of Environmental Medicine ${ }^{1}$ and Medicine, ${ }^{2}$ University of Umeå, Department of Occupational Medicine, ${ }^{3}$ University Hospital Umeå, and Health Services Research Unit, ${ }^{4}$ Swedish Medical Research Council and University of Umeå, Sweden

ABSTRACT The study is based on the work histories and mortality data for 3832 male workers first employed before 1967 at a copper smelter in northern Sweden and followed up from 1950 to 1981. From the 3832 workers a lead cohort consisting of 437 workers employed for at least three years at sites with considerable lead exposure during 1950-74 was selected. These workers had regularly had blood lead measurements performed since 1950. Based on the cumulative blood lead dose 1950-74 and peak blood lead values, the cohort was subdivided into high mean, low mean, high peak, and low peak groups. Standardised mortality ratios (SMR) were calculated for the six groups using general and local reference populations. The original cohort of 3832 workers showed considerable excess of deaths for total mortality, malignant neoplasms especially lung and stomach cancer, ischaemic heart diseases, and cerebrovascular diseases when compared with the general population. In the lead cohort where the workers had been subjected to a considerable lead exposure only the raised SMR for lung cancer was sustained (SMR = 162; not significant). No significant differences were found between high lead and low lead exposed smelter workers.

Smelter workers in the largest copper smelter in Sweden are exposed to toxic dusts, fumes, and gases. Lead, a common air pollutant in the smelter, has been given particular attention in this study. From the early days of the smelter urine and blood lead analyses have been undertaken as well as dust measurements in the working environment.

A study of lead battery and smelter workers showed a significantly increased total mortality in the two cohorts, the standardised mortality ratio (SMR) being 107 for the first and 113 for the second. ${ }^{1}$ In the battery plants the excess number of deaths largely reflected significantly raised SMRs for other hypertensive disease (mainly renal), chronic nephritis, malignant neoplasms, and a group of ill defined conditions. Among the lead smelter workers the pattern was similar, with a significant number of excess deaths from other hypertensive disease, hypertensive heart disease, chronic nephritis, ill defined conditions, and external causes.

According to the investigators, it was not possible to relate the observed mortality to levels of lead exposure owing to the small amount of quantitative information before $1960 .^{1}$ Many members of both

Accepted 3 March 1986 cohorts, however, had worked during periods when exposures to lead greatly exceeded current standards.

The Rönnskär smelter is a unique work environment for dose-response studies as exposure mapping and health examinations of the workers have been undertaken for many years. By comparing the doseresponse data systematically, it was thought that the mortality pattern consequent lead exposure might be further evaluated.

\section{Lead toxicity}

Lead may cause acute and chronic intoxications, acute gastrointestinal colic, acute and chronic lead encephalopathy, peripheral neuropathy, and anaemia. Long term exposure may lead to irreversible functional and morphological renal changes; intense interstitial fibrosis, tubular atrophy, and dilatation. ${ }^{2}$

Malignant and benign renal neoplasms are induced in rats and mice by oral or parenteral administrations of various types of inorganic lead compounds in high doses. $^{3-8}$ Lead oxide mixed with benzo(a)pyrene produces lung tumours in hamsters. ${ }^{9}$ Lead subacetate induces lung adenomas in mice ${ }^{10}$ and cerebral gliomas in rats. ${ }^{11}$ In vitro, lead acetate induces a dose related neoplastic transformation in Syrian hamster embryo 
cells. ${ }^{12}$ Lead oxide enhances the transformation produced in Syrian hamster embryo cells by SA7 virus. ${ }^{13}$

An update ${ }^{1}$ of an earlier mortality analyses of lead smelter and battery workers ${ }^{14} 15$ showed an excess of malignant neoplasms in the two cohorts, but the raised SMRs were statistically significant only for gastric and lung cancers in the battery plant workers. No conclusive evidence, however, of the carcinogenic properties of lead in man has yet been presented. Dingwall-Fordyce and Lane, in a study of battery plant employees and pensioners, concluded that there was no evidence to suggest that malignant disease was related to lead absorption. ${ }^{16}$ In their study the number of deaths from malignant neoplasms was slightly fewer than expected in the groups with the highest lead exposure. Similar results were reported by Malcolm and Barnett, who found 157 deaths due to neoplasms, with 159.5 expected, among 1898 male battery plant pensioners. ${ }^{17}$ McMichael and Johnson compared the cause of death profile among 140 deceased Australian lead smelter workers with a history of lead poisoning with that of 695 other male decedents (predominantly non-office production workers). ${ }^{18}$ Even after adjustment for the effect of excess deaths from non-malignant disease, the proportion of deaths from cancer was only $70 \%$ of that of the comparison group. Thus lead poisoning did not appear to increase the risk of cancer.

\section{Rönnskär smelter}

The production of lead at Boliden Metall, Rönnskär, is based on two processes, flash smelting and the Kaldo technique. Both methods have been developed by the company. In flash smelting the concentrate is smelted in an electric furnace without preceding roasting or sintering, and the furnace lead is then converted and refined. In the Kaldo furnace pelletised flue dust, slag-forming agents, and coke are charged and smelted. After smelting the metal compounds are reduced to metals.

The major pathways for the production of lead within the smelter are as follows:

1 Copper roaster-copper smelting furnaceslag fuming-zinc clinker furnace $(\mathrm{PbO}$, $\mathrm{PbSO}_{4}$ )- lead Kaldo furnace- $-\mathrm{Pb}^{0}$

2 Copper roaster-copper smelting furnacecopper converter-converter dust (PbO, $\mathrm{PbSO}_{4}$ ) - lead Kaldo furnace- $\mathrm{Pb}^{0}$

3 Concentrates-lead smelting furnace-lead converter-lead refinery- $\mathrm{Pb}^{\mathbf{0}}$

4 Concentrates-lead smelting furnace-slag fuming-lead Kaldo furnace-- $\mathbf{P b}^{\mathbf{0}}$

The concentrate contains $70-75 \%$ of lead, $14 \%$ of sulphur, $1-3 \%$ of zinc, $2 \%$ of iron, and $5-6 \%$ of silica. Moreover, the concentrate contains some silver and copper and traces of cadmium, bismuth, tin, and antimony. After the completion of refining the lead is at least $99.99 \%$ pure.

The production figures for lead in recent years have been of the order of 55-65000 tons. About 55000 tons are produced in the lead plant and about 6-7000 tons in the lead Kaldo plant.

\section{Dust measurements}

The company has measured dust for many years. The measurement strategies were systematised in the 1940s and considerably extended after 1950 . Total dust sampling at fixed stations has dominated and respirable dust sampling has only recently been introduced. At the lead refinery about $70 \%$ of the dust is respirable, this proportion is higher for workers directly dealing with smelting materials and lower for workers handling crushed raw materials.

\section{Material and methods}

The present study was based on all male workers first employed at the Rönnskär smelter before 1967 for total periods of at least three months and followed up from 1950 to 1981. Detailed work histories have been compiled from the company records. In Sweden an individual code system with civic numbers was established in 1947. Thus each worker can be traced in the population and cause of death registers at the National Bureau of Statistics. Of the 3832 workex thus followed up, 1188 had died before the closing date of this study (1 January 1982). Causes of death were coded according to the WHO International Classification of Diseases (8th revision).

From the 3832 (cohort A), a smaller cohort (group B) was selected (fig 1). The latter group consisted of 437 workers working for three years or more at work sites with verified high lead exposure from 1950 to 1974. These workers had regularly had their blood lead concentration measured since 1950 and the annual mean blood lead value could be calculated for each individual from 1950 to 1974.

Blood lead analyses were performed at the smelter by emission spectrometry from 1950 to 1969 and by

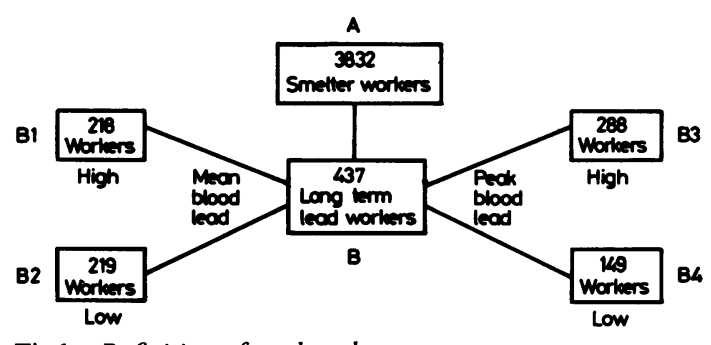

Fig 1 Definition of study cohorts. 
atomic absorption spectrophotometry from 1967 to 1986. The two methods were used in parallel from 1967 to 1969. The results from atomic absorption spectrophotometry showed a narrower standard deviation and somewhat lower blood lead values compared with the emission spectrometry method (difference between methods $\leqslant 10 \%$ ). For quality control purposes, an exchange of blood lead samples with laboratories in West Germany and the United Kingdom has taken place since 1950 with satisfactory results. ${ }^{1920}$

Since the beginning of the 1970s the laboratory at the smelter has participated in a national quality control programme originating from the National Board of Occupational Health and Safety in Stockholm. ${ }^{21-23}$ Six to eight samples of blood containing certified lead concentrations are sent to the laboratories included in the control programme twice a year. Since 1976 the laboratory at the smelter has consistently produced results in good agreement with the expected concentrations. The results from the start of the quality control programme up to 1975 were also satisfactory according to one of the originators of the control programme ( $\AA$ Swensson, personal communication, 1985).

The accumulated lead exposure from 1950 to 1974 was calculated as a cumulative blood lead dose by a summation of the annual mean blood lead values for each worker. Thus all workers in group B were ranked from 1-437 according to the sum of the cumulative blood lead dose.

Based on the median value $(478.5 \mu \mathrm{g} \mathrm{Pb} / 100 \mathrm{ml}$ of blood) of the cumulative blood lead dose, group B was subdivided (fig 1) into a group with high exposure (group B1 = high mean values; $n=218$ ) and one with low exposure (group B2 = low mean values; $n=219$ ). Group B was also subdivided (fig 1 ) from the peak lead blood values into those who at least once had exceeded a B-Pb of $70 \mu \mathrm{g} / 100 \mathrm{ml}$ of blood (3.4 umol/l) (group $\mathrm{B} 3=$ high peak values; $\mathrm{n}=288$ ) and into those who had never exceeded this level (group $B 4=$ low peak values; $n=149$ ). Of group B3 with high peak lead values, 187 workers also belonged to group B1 with high mean lead values.

Approximately $30 \%$ of the workers in group A had worked in only one place in the smelter whereas $35 \%$ had worked in more than five places; $14 \%$ had changed work within the smelter 10 times or more.

In group A 1188 workers and in group B 85 workers had died before 1 January 1982; 48 from group B1 and 37 from group B2.

The expected mortality was calculated from the national and county mortality rates, specified for cause, sex, five year age groups, and calendar periods. Two sided statistical tests were used. SMRs and test based $95 \%$ confidence limits were calculated according to Miettinen. ${ }^{24}$

\section{Results}

Lead exposure at the Rönnskär smelter has decreased gradually since 1950 . In 1950 the mean blood lead concentration for all samples taken that year was $58.2 \mu \mathrm{g} \mathrm{Pb} / 100 \mathrm{ml}(2.8 \mu \mathrm{mol} / \mathrm{l})$ in group $\mathrm{B}$ compared with $33.6 \mu \mathrm{g} \mathrm{Pb} / 100 \mathrm{ml}(1.6 \mu \mathrm{mol} / \mathrm{l})$ in 1974 (fig 2).

The total mortality for different age categories of all smelter workers and lead exposed smelter workers (cohorts A and B) standardised against Swedish men $1950-81$ is presented in table 1 . The relative mortality for ages above 45 is considerably lower in group B who had high lead exposure. The SMR of 77 in group $B$ is significantly reduced $(62.95 ; 95 \%$ confidence limits).

The different causes of death in the cohorts were compared with the general Swedish population (fig 3 and table 2). The total mortality $(S M R=115$; $\mathrm{p}<0.001$ ), the mortality from all malignant neoplasms $(S M R=114 ; p<0.05)$, and the mortality from circulatory diseases $(S M R=120 ; p<0.001)$ were increased in cohort $A$. Increased SMRs were also noted for stomach cancer $(S M R=143 ; p<0.05)$, ischaemic heart diseases (SMR $=119 ; \mathrm{p}<0.001)$, and cerebrovascular diseases $(\mathrm{SMR}=129 ; \mathrm{p}<0.01)$. The number of observed cases of lung cancer $(90$

Table 1 Total mortality 1950-81 for all smelter workers and long term exposed lead workers by reference to the Swedish male population

\begin{tabular}{|c|c|c|c|c|c|c|}
\hline \multirow[b]{3}{*}{ Age } & \multicolumn{3}{|c|}{$A(n=3832)$} & \multicolumn{3}{|l|}{$B(n=437)$} \\
\hline & \multicolumn{3}{|c|}{ All smelter workers } & \multicolumn{3}{|c|}{ Long term exposed lead workers } \\
\hline & Person years & $\begin{array}{l}\text { Observed No of } \\
\text { deaths }\end{array}$ & $S M R$ & Person years & $\begin{array}{l}\text { Observed No of } \\
\text { deaths }\end{array}$ & $S M R$ \\
\hline $\begin{array}{l}15-44 \\
45-54 \\
55-64 \\
65-74 \\
\geqslant 75 \\
\text { Total }\end{array}$ & $\begin{array}{r}42945 \\
26309 \\
19989 \\
9413 \\
1908 \\
100564\end{array}$ & $\begin{array}{r}68 \\
167 \\
328 \\
407 \\
218 \\
1188\end{array}$ & $\begin{array}{r}86 \\
117 \\
117 \\
119 \\
113 \\
115\end{array}$ & $\begin{array}{r}5064 \\
3602 \\
2613 \\
1023 \\
105 \\
12407\end{array}$ & $\begin{array}{r}8 \\
10 \\
22 \\
37 \\
8 \\
85\end{array}$ & $\begin{array}{r}83 \\
52 \\
61 \\
103 \\
88 \\
77\end{array}$ \\
\hline
\end{tabular}


710

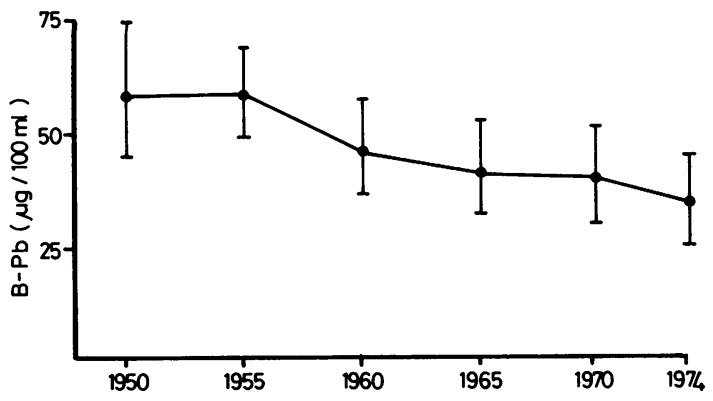

Fig 2 Mean annual blood lead concentration $( \pm S D)$ for exposed smelter workers (group B) 1950-74.

compared with $41 \cdot 2$ and $27 \cdot 2$ expected from national and county figures respectively) was statistically significant $(\mathrm{p}<0.001)$.

In group B only the raised mortality for lung cancer was sustained, but was not statistically significant. Figure 3 shows that for each of the disease categories studied, group A had higher SMRs than group B when comparing each group with the general population. No consistent dose-response patterns can be seen when group B is subdivided in accordance with mean or peak blood lead values.

The smelter is in the county of Västerbotten for which the mortality pattern differs from Sweden as a whole. Compared with the general population, the county population has a somewhat higher total mortality and a higher mortality from diseases of the circulatory system, cardiovascular diseases, cerebrovascular diseases, and a considerably higher mortality for stomach cancer. The local population, however, has a lower total cancer mortality, especially for lung cancer, compared with the general population. The SMRs for the groups in this study are thus changed accordingly when compared with the local population.

SMRs for all malignant neoplasms, lung cancer, and stomach cancer in groups A, B, B1, B2, B3, and B4 were also calculated using a latency period of 15

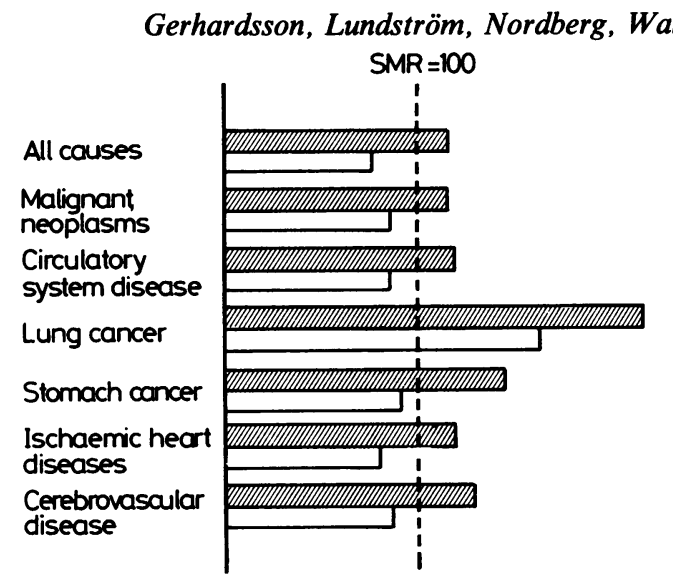

All smelter workers ( group A)

Long term exposed lead

workers ( group B)

Fig 3 Standardised mortality pattern 1950-81 for all smelter workers (group A) and lead smelter workers (group $B)$ by reference to the Swedish male population.

years. Early deaths unlikely to be related to exposure were thus eliminated. The changes in SMRs were, however, marginal.

\section{Discussion}

The occupational epidemiology "exposure" is usually measured in terms of time and place, rarely in doseco The combined information from work histories and? long term individual blood level measurements in this study have enabled a more precise characterisation of the exposure than calculations from spot analyses, which often differ from the actual doses inhaled.

The analysis of a possible association between mortality and lead exposure was carried out by successive refinements of "exposure." The original group (A) of all smelter workers had an excess mortality relative to the national and local populations. This was particularly the case for lung cancer. When considering only those with long term exposure to lead (group B), the

Table 2 Mortality (observed/expected number of deaths) 1950-81 by lead exposure category and cause of death. Expected numbers based on the Swedish male population. (Size of cohorts within parentheses)

\begin{tabular}{|c|c|c|c|c|c|c|}
\hline \multirow[b]{2}{*}{ Cause of death } & \multicolumn{6}{|l|}{ Study cohort } \\
\hline & $\begin{array}{l}A \\
(3832)\end{array}$ & $\begin{array}{l}B \\
(437)\end{array}$ & $\begin{array}{l}B 1 \\
(218)\end{array}$ & $\begin{array}{l}B 2 \\
(219)\end{array}$ & $\begin{array}{l}B 3 \\
(288)\end{array}$ & $\begin{array}{l}B 4 \\
(149)\end{array}$ \\
\hline $\begin{array}{l}\text { All causes } \\
\text { Malignant neoplasms } \\
\text { Circulatory diseases } \\
\text { Lung cancer } \\
\text { Stomach cancer } \\
\text { Ischaemic heart disease } \\
\text { Cerebrovascular disease }\end{array}$ & $\begin{array}{c}1188 / 1036 \cdot 5 \\
270 / 237 \cdot 7 \\
612 / 511 \cdot 5 \\
90 / 41 \cdot 2 \\
46 / 32 \cdot 1 \\
421 / 353 \cdot 2 \\
109 / 84 \cdot 7\end{array}$ & $\begin{array}{l}85 / 110 \cdot 6 \\
23 / 26 \cdot 4 \\
45 / 52 \cdot 6 \\
8 / 5 \cdot 0 \\
3 / 3 \cdot 2 \\
31 / 37 \cdot 6 \\
8 / 7 \cdot 9\end{array}$ & $\begin{array}{l}48 / 62 \cdot 3 \\
15 / 15 \cdot 0 \\
25 / 30 \cdot 0 \\
5 / 2 \cdot 9 \\
2 / 1 \cdot 8 \\
17 / 21 \cdot 6 \\
5 / 4 \cdot 5\end{array}$ & $\begin{array}{c}37 / 48 \cdot 4 \\
8 / 11 \cdot 4 \\
20 / 22 \cdot 6 \\
3 / 2 \cdot 1 \\
1 / 1 \cdot 4 \\
14 / 16 \cdot 1 \\
3 / 3 \cdot 4\end{array}$ & $\begin{array}{c}60 / 75 \cdot 1 \\
16 / 17 \cdot 9 \\
32 / 35 \cdot 8 \\
4 / 3 \cdot 4 \\
3 / 2 \cdot 2 \\
22 / 25 \cdot 6 \\
7 / 5 \cdot 4\end{array}$ & $\begin{array}{c}25 / 35 \cdot 5 \\
7 / 8 \cdot 5 \\
13 / 16 \cdot 8 \\
4 / 1 \cdot 6 \\
0 / 1 \cdot 0 \\
9 / 12 \cdot 0 \\
1 / 2 \cdot 5\end{array}$ \\
\hline
\end{tabular}


excess number of deaths, with the possible exception of lung cancer, disappeared. No clear dose-response pattern was seen when comparing high lead and low lead exposed groups (high mean $v$ low mean; high peak $v$ low peak). Since blood lead values became available only in 1950 , there could have been up to 20 years of unmonitored exposure to lead in some members in cohort $B$. Nevertheless, this strengthens rather than weakens the evidence that lead is not a carcinogen in man. Our findings agree with earlier published reports showing no increased overall excess risk of cancer for workers exposed to lead. ${ }^{16-18}$

The study has focused on the disease categories in table 2; figures for other disease categories have not been included because of their small numbers. Two observed cases of uraemia from kidney disease which might partly be caused by exposure to lead was equal to the expected number $(2 \cdot 2)$.

An increased mortality from different malignancies (lung cancer, for example) has previously been reported from the smelter. ${ }^{25} 26$ The excess total mortality for the smelter workers was $10-20 \%$ compared with the general and local populations. ${ }^{27}$ For tumours and circulatory disease the excess were $30-40 \%$. Of the tumours, the increased mortality was mainly due to lung cancer, for which the risk was threefold compared with the general Swedish population and fivefold relative to the local population. A doseresponse analysis clearly indicated that the roasters and arsenic departments were places of particular risk for the development of cancer, especially lung cancer. In another extensive study increased deaths in lead battery workers were reported from stomach and lung cancers. ${ }^{1}$ In the study of Cooper $e t$ al, however, the cohorts were not divided into exposure categories and thus a dose-response analysis could not be undertaken. Smoking habits were also missing as they are in our study. Increased rates of lung cancer are usually seen in blue collar workers who smoke more than average. In our study, however, there was no excess of deaths from another smoking associated disease, coronary heart disease, in lead smelter workers exposed long term.

All the smelter workers had a mixed exposure. In group $A$ about $31 \%$ had, for some period since 1928 , been working at the roasters, at the arsenic departments, or at both ( $10 \%$ of group $A \geqslant 5$ years). The corresponding figures for groups B, B1, B2, B3, and $B 4$ were $41 \%$ ( $13 \%$ of group $B \geqslant 5$ years), $41 \%$, $40 \%, 44 \%$, and $33 \%$ respectively. The smelter workers were exposed to several air pollutants including metals and semi-metals such as antimony, arsenic, cadmium, chromium, cobalt, lanthanum, lead, selenium, and zinc; organic and inorganic carcinogens, polyaromates such as benzo(a)pyrene, short lived free radicals, and air ions are also frequent.
The multifactorial exposure profile has been discussed earlier ${ }^{28-33}$ A protective effect of selenium against lung cancer has been indicated ${ }^{32}$ and individual case analyses show that high concentrations of lead are connected with high concentrations of several other metals.

In conclusion the prolonged exposure to lead at work in this study, even under conditions regarded as unacceptable today, has not given rise to a significant excess of neoplasms. No association has been shown between exposure to lead and renal neoplasms (1 observed) which, however, has been reported in some animal experiments. ${ }^{3-8}$

Financial support was given by the Swedish Work Environment Fund project No 83-0127.

Exposure data extracted and registered at the Medical Information Handling Unit, MEDIFO, at Umeå University.

Requests for reprints to: Dr Gerhardsson, Department of Environmental Medicine, University of Umeå, S-901 87 Umeå, Sweden.

\section{References}

1 Cooper WC, Wong O, Kheifets L. Mortality among employees of lead battery plants and lead-producing plants, 1947-1980. Scand J Work Environ Health 1985;11:331-45.

2 Tsuchiya K. Lead. In: Friberg L, Nordberg GF, Vouk VB, eds. Handbook on the toxicology of metals. Amsterdam: Elsevier/North-Holland Biomedical Press, 1979:451-84.

3 Zollinger HU. Durch chronische Bleivergiftung erzeugte Nierenadenome und -carcinome bei Ratten und ihre Beziehungen zu den entsprechenden Neubildungen des Menschen. Virchows Archiv 1953;323:694-710.

4 Boyland E, Dukes CE, Grover PL, Mitchley BCV. The induction of renal tumours by feeding lead acetate to rats. Br $J$ Cancer 1962;16:283-8.

5 Roe FJC, Boyland E, Dukes CE, Mitchley BCV. Failure of testosterone or xanthopterin to influence the induction of renal neoplasms by lead in rats. $\mathrm{Br} J$ Cancer 1965;19:860-6.

6 Van Esch GJ, Kroes R. The induction of renal tumours by feeding basic lead acetate to mice and hamsters. Br $J$ Cancer 1969;23:765-71.

7 Zawirska B, Medras K. Tumoren und Störungen des Porphyrinstoffwechsels bei Ratten mit chronischer experimenteller Bleiintoxikation. I. Morphologische Studien. Zentralbl Allg Pathol 1968;111:1-12.

8 Zawirska B, Medras K. The role of the kidneys in disorders of porphyrin metabolism during carcinogenesis induced with lead acetate. Arch Immunol Therap Exp 1972;20:257-72.

9 Kobayashi N, Okamoto T. Effects of lead oxide on the induction of lung tumours in Syrian hamsters. $J$ Natl Cancer Inst 1974;52:1605-10.

10 Poirier LA, Theiss JC, Arnold LJ, Shimkin MB. Inhibition by magnesium and calcium acetates of lead subacetate- and nickel acetate-induced lung tumours in strain A mice. Cancer Res 1984;44:1520-2.

11 Oyasu R, Battifora HA, Clasen RA, McDonald JH, Hass GM. Induction of cerebral gliomas in rats with dietary lead subacetate and 2-acetylaminofluorene. Cancer Res 1970;30: 
1248-61.

12 DiPaolo JA, Nelson RL, Casto BC. In vitro neoplastic transformation of Syrian hamster cells by lead acetate and its relevance to environmental carcinogenesis. Br J Cancer 1978;38:452-5.

13 Casto BC, Meyers J, DiPaolo JA. Enhancement of viral transformation for evaluation of the carcinogenic or mutagenic potential of inorganic metal salts. Cancer Res 1979;39:193-8.

14 Cooper WC, Gaffey WR. Mortality of lead workers. J Occup Med 1975;17:100-7.

15 Cooper WC. Cancer mortality patterns in the lead industry. Ann NY Acad Sci 1976;271:250-9.

16 Dingwall-Fordyce I, Lane RE. A follow-up study of lead workers. Br J Ind Med 1963;20:313-5.

17 Malcolm D, Barnett HAR. A mortality study of lead workers 1925-76. Br J Ind Med 1982;39:404-10.

18 McMichael AJ, Johnson HM. Long-term mortality profile of heavily-exposed lead smelter workers. $J$ Occup Med 1982;24:375-8.

19 Hoschek R. Parallelbestimmungen des Bleispiegels in verschiedenen Instituten. Archiv für Gewerbepathologie und Gewerbehygiene 1963;20:195-216.

20 Holmqvist I. Monitoring and control of lead health risks at a Swedish smelter. London: Lead Development Association, 1976.

21 Vahter M, ed. Assessment of human exposure to lead and cadmium through biological monitoring. (Prepared for UNEP and WHO.) Stockholm: National Swedish Institute of Environmental Medicine and Karolinska Institute (Department of Environmental Hygiene), 1982:1-136.

22 Friberg L, Vahter M. Assessment of exposure to lead and cadmium through biological monitoring. Results of a UNEP/WHO global study. Environ Res 1983;30:95-128.
23 Wrangskog K. Interlaboratoriekontroll avseende bestämning av bly i blod. Arbete och Hälsa 1984;15:1-25. (In Swedish.)

24 Miettinen $O$. Estimability and estimation in case-referent studies. Am J Epidemiol 1976;103:226-35.

25 Axelson O, Dahlgren E, Jansson C-D, Rehnlund SO. Arsenic exposure and mortality: a case-referent study from a Swedish copper smelter. Br J Ind Med 1978;35:8-15.

26 Pershagen G, Wall S, Taube A, Linnman L. On the interaction between occupational arsenic exposure and smoking and its relationship to lung cancer. Scand $J$ Work Environ Health 1981;7:302-9.

27 Wall S. Survival and mortality pattern among Swedish smelter workers. Int J Epidemiol 1980;9:73-87.

28 Brune D, Nordberg G, Wester PO. Distribution of 23 elements in the kidney, liver and lungs of workers from a smeltery and refinery in north Sweden exposed to a number of elements and of a control group. Sci Total Environ 1980;16:13-35.

29 Wester PO, Brune D, Nordberg G. Arsenic and selenium in lung, liver and kidney tissue from dead smelter workers. $\mathrm{Br} J$ Ind Med 1981;38:179-84.

30 Gerhardsson L, Brune D, Nordberg GF, Wester PO. Antimony in lung, liver and kidney tissue from deceased smelter workers. Scand J Work Environ Health 1982;8:201-8.

31 Gerhardsson L, Brune D, Nordberg GF, Wester PO. Chromium, cobalt and lanthanum in lung, liver and kidney tissue from deceased smelter workers. Sci Total Environ 1984;37:233-46.

32 Gerhardsson L, Brune D, Nordberg GF, Wester PO. Protective effect of selenium on lung cancer in smelter workers. $\mathrm{Br} \mathrm{J}$ Ind Med 1985;42:617-26.

33 Nordberg GF, Pershagen G. Metal interactions in carcinogenesis. Effects of mixed exposure on carcinogenic response. Toxicol Environ Chem 1984;9:63-78. 